\title{
Sap Transmission and Detection of Sunflower Necrosis virus in Sunflower
}

\author{
Ravi Kumar*, B. Jagadeesha, N. Gajanana Kustagi, K.R. Lingamurthy, \\ N. Ashoka and Nagaraju
}

College of Horticulture, Munirabad-583233, Koppal, Karnataka

*Corresponding author

\section{A B S T R A C T}

\section{Keywords}

Sunflower necrosis virus, Tobacco streak virus and sap inoculation

\section{Article Info}

Accepted:

22 January 2019

Available Online:

10 February 2019
The present study was carried out to know the sap transmission nature of sunflower necrosis virus and detection by serological and molecular means. The disease was successfully transmitted through mechanical sap using $0.05 \mathrm{M}$ potassium phosphate buffer. A maximum transmission of 52.33 per cent on cultivar KBSH-44, 51.33 per cent on KBSH-1, and 48.33 per cent on Morden. Under artificial inoculation, the newly emerged leaves showed slight downward curling, puckering and chlorosis followed by necrosis. The sunflower genotypes subjected for serological detection by using DAC-ELISA a positive reaction with Tobacco Streak Virus (TSV) antisera was obtained, further, The RT-PCR was performed using RKJ primers specific for the coat protein gene of TSV and resulted in an amplicon of approximately 700bp. These results thus prove the transmissible nature of SNV through mechanical sap.

\section{Introduction}

Sunflower (Helianthus annuus Linn.), is an important proteinaceous oilseed crop and a member of Asteraceae family. It is one of the world's leading edible oilseed crop and ranks third next to soybean and groundnut. The oil content in seed is about 40-45 per cent with high amount of polyunsaturated fatty acids (44-76 \% linoleic acid and 14-43\% oleic acid). Presently sunflower is mainly grown for its oil for culinary purposes, preparation of vanaspati and in the manufacture of soaps and cosmetics. It is especially recommended for cardiac patients.
Among the several limiting factors for successful sunflower cultivation, susceptibility to diseases is one of the major constraints. Among the diseases the most important ones are Alternaria leaf spot, rust, downy mildew and many virus diseases (Kolte, 1985). Several virus and virus like diseases viz., sunflower mosaic, rugose mosaic, yellow ring mosaic, yellow mosaic, yellow spot, chlorotic leaf mosaic, greening and cucumber mosaic, Phytoplasma, strains of tomato big bud, aster yellows and phyllody have been reported on sunflower (Nagaraju, 1995). A new viral 
disease was noticed around Bangalore, Kolar and some belts of Karnataka causing severe yield loss (Anon., 1997; Singh et al., 1997). The Sunflower Necrosis Disease (SND) disease was first noticed in the country during 1997 at Bagepalli of Kolar district of Karnataka in seed production plots. Subsequently, the disease was reported throughout the states of Karnataka, Tamil Nadu and Andra Pradesh (Nagaraju et al., 1998).

Prasada Rao et al., (2000) concluded that the causal agent of Sunflower Necrosis Disease was a strain of tobacco streak virus (TSV) belonging to Ilarvirus group. The virus is transmitted through mechanical sap inoculation from infected plant to healthy one (Linga Reddy, 2003). To understand the nature of transmission and detection of the disease present investigations were carried out.

\section{Material and Methods}

\section{Transmission of SNV through Mechanical sap inoculation}

\section{Preparation of inoculum}

The mechanical sap inoculation of the sunflower necrosis virus was carried out using $0.05 \mathrm{M}$ Phosphate buffer. The Young tender leaves from the infected sunflower seedlings showing typical symptoms of SNV were collected, washed thoroughly in running tap water to remove dirt and blot dried.

The leaf sample was macerated in clean sterilized pestle and mortar kept in a container with ice cubes by adding chilled phosphate buffer $(1 \mathrm{ml} / \mathrm{g}$ of leaf tissue). After thorough maceration, extract was filtered through two folds of muslin cloth and $100 \mathrm{mg}$ celite was added to the extract. The resultant extract was used as standard inoculum for sap inoculation.

\section{Method of inoculation}

Test sunflower plants were raised using healthy seeds in 6-inch height polythene bags containing soil, sand and compost in 2:1:1 ratio (w/w) and maintained in glasshouse. A small piece of sterilized absorbent cotton wool soaked in standard inoculum was gently rubbed on the upper surface of leaves of the test plants. The seedlings at two leaves stage were used for the experiment. During inoculation the leaves were supported from below with left-hand palm to avoid any injury and to provide uniform pressure and spread of inoculum. The inoculated leaves were washed ten minutes after inoculation with a jet of sterile water from squeeze bottle to remove excess inoculum. Each set of plants inoculated thus was labeled separately and kept in glasshouse. These plants were maintained for symptom expression up to 30-40 days. The test plants were inoculated on second and fourth fully expanded leaves. The inoculated plants were labeled and kept for symptom expression in glasshouse and observed up to 40 days.

\section{Prep Serological detection of sunflower necrosis virus by using DAC-ELISA aration of inoculum}

The plant samples from glasshouse were collected and tested by direct antigen coated enzyme linked immunosorbent assay (DACELISA) protocol with Tobacco streak virus antisera and alkaline phosphatase (ALP) enzyme and p-nitrophenylphosphate (pNPP) system was employed by following the standardized protocol in our laboratory.

\section{Molecular detection of Sunflower Necrosis Virus using Reverse Transcriptase- Polymerase Chain Reaction (RT-PCR)}

The primer is derived from the Coat Protein (CP) gene sequence of Tobacco Streak Virus. The genome sense primer 5' 
ATGAATACTTTGATCCAAGG 3' was derived from the beginning of the first 20 bases of the coding region. The genome antisense primer $5^{\prime}$ TCAGTCTTGATTCACCAG 3' represented last 18 bases of the coding region of the $\mathrm{CP}$ gene.

The RNA was extracted according to protocol of RNeasy mini kit (Qiagen). The RNA thus isolated from the purified sample was used for RT-PCR. First cDNA was synthesized from viral RNA in a $20 \mu 1$ reaction using MmuLVRT enzyme (Fermentas). RT reaction was set up by adding $8 \mu \mathrm{l}$ of RNA sample and one $\mu \mathrm{l}$ of reverse primer in a $0.2 \mathrm{ml}$ polypropylene tube. This mixture was heated to $70^{\circ} \mathrm{C}$ for 5 min. All reaction components including 4.0 $\mu 1$ Rnase free water, $2.5 \mu 15 \mathrm{x}$ MMuLV reaction buffer (MBI, Fermentas), $2.5 \mu 110 \mathrm{mM}$ dNTPs, $0.5 \mu 1 \mathrm{MMuLV}$ reverse transcriptase $(200 \mathrm{U} / \mu 1$, MBI, Fermentas) were then added to the tube and incubated at $4^{\circ} \mathrm{C}$ for $30 \mathrm{sec}, 42^{\circ} \mathrm{C}$ for 60 $\min$. The reaction was stopped by heating the mixture at $75^{\circ} \mathrm{C}$ for $10 \mathrm{~min}$ in a thermal cycler.

The cDNA synthesized by reverse transcription was amplified by PCR. All the reaction components were procured from MBI Fermentas. PCR reaction mixture of $25 \mu 1$ was prepared as follows: Deionized nuclease free water $12.0 \mu 1,10 \mathrm{X}$ PCR buffer $02.5 \mu 1,25 \mathrm{mM}$ dNTPS02.0 $\mu 1,25 \mathrm{mM} \mathrm{MgCl}_{2} \quad 02.0 \mu \mathrm{l}$, Forward primer $(20 \mathrm{pmol} / \mu \mathrm{l}) \quad 00.5 \mu \mathrm{l}$, Reverse primer $(18 \mathrm{pmol} / \mu \mathrm{l}) \quad 00.5 \mu \mathrm{l}$, Taq DNA polymerase $(3 \mathrm{U} / \mu \mathrm{l}) 00.3 \mu \mathrm{l}$, DNA sample template (50-60ng) $05.0 \mu 1$.

The PCR amplification was carried out in a thermal cycler with the following conditions: Initial denaturation $94 \mathrm{oC}$ for $2 \mathrm{~min}$, Denaturation $94^{\circ} \mathrm{C}$ for $45 \mathrm{sec}$, annealing $48^{\circ} \mathrm{C}$ for $45 \mathrm{sec}$, Extension $72^{\circ} \mathrm{C}$ for $1.30 \mathrm{~min}$, Final extension $72^{\circ} \mathrm{C}$ for $20 \mathrm{~min}$ and Hold at $4^{\circ} \mathrm{C}$. The amplified DNA fragments were electrophorized in 1\% agarose gel, stained with ethidium bromide and visualized and documented (Sambrook et al., 1989).

\section{Results and Discussion}

The results revealed that the per cent transmission of SNV through mechanical sap inoculation ranged from 52.33 to 48.33 (Table 1) in sunflower hybrids KBSH-1, KBSH-44 and Morden. Highest mean per cent transmission was observed in case of the KBSH-44 (52.33), followed by KBSH-1 (51.33) and Morden (48.33). Ajith Prasad (2004) reported that the disease could be transmitted through sap when standard inoculum prepared from potassium phosphate buffer was used and the percentage transmission ranged from 19 to 22 per cent in the different sunflower hybrids.

Under artificial inoculation, the newly emerged leaves of the inoculated plants showed slight downward curling in 5-6 days after inoculation. Such leaves developed chlorotic spots in 8-10 days after inoculation. The chlorotic spots later turned necrotic with necrosis extending through petiole causing necrosis of the tip in 15-18 days after inoculation (Plate 1). The symptoms observed during the present investigations were similar to that reported by Nagaraju et al., (1998), Anil Kumar (1999), Shivasharanayya (2000) and Ajith Prasad (2004) under laboratory and field conditions.

The sunflower genotypes (KBSH 1, KBSH 44, Morden) after subjecting for artificial inoculation of the virus through mechanical sap were subjected for DAC-ELISA (Table1). A positive reaction with Tobacco Streak Virus (TSV) antisera was obtained in all the three genotypes indicating the presence of SNV in the leaf samples.

These results thus prove the transmissible nature of SNV through mechanical sap method. Similar results were reported by Linga Reddy (2003) and Linga Reddy and Nagaraju (2006). 
Table.1 Mechanical sap inoculation of Sunflower Necrosis Virus (SNV)

\begin{tabular}{|c|c|c|c|c|c|c|}
\hline \multirow{2}{*}{$\begin{array}{l}\text { Sl. } \\
\text { No. }\end{array}$} & \multirow[t]{2}{*}{ Cultivar } & \multirow[t]{2}{*}{ Replication } & \multicolumn{2}{|c|}{ No. of plants } & \multirow{2}{*}{$\begin{array}{l}\text { Mean transmission } \\
\quad \text { (Per cent) }\end{array}$} & \multirow{2}{*}{$\begin{array}{l}\text { Dtection by } \\
\text { DAC ELISA }\end{array}$} \\
\hline & & & Inoculated & Infected & & \\
\hline \multirow[t]{3}{*}{1.} & \multirow[t]{3}{*}{ KBSH-1 } & I & 100 & 50 & \multirow[t]{3}{*}{51.33} & \multirow[t]{3}{*}{ Positive } \\
\hline & & II & 100 & 55 & & \\
\hline & & III & 100 & 49 & & \\
\hline \multirow[t]{3}{*}{2.} & \multirow[t]{3}{*}{ KBSH-44 } & I & 100 & 57 & \multirow[t]{3}{*}{52.33} & \multirow[t]{3}{*}{ Positive } \\
\hline & & II & 100 & 48 & & \\
\hline & & III & 100 & 52 & & \\
\hline \multirow[t]{4}{*}{3.} & \multirow[t]{3}{*}{ Morden } & I & 100 & 45 & \multirow[t]{3}{*}{48.33} & \multirow[t]{3}{*}{ Positive } \\
\hline & & II & 100 & 49 & & \\
\hline & & III & 100 & 51 & & \\
\hline & \multicolumn{4}{|c|}{ Mean transmission (\%) } & 50.66 & \\
\hline
\end{tabular}

Plate.1 Symptoms on sunflower plant upon sap inoculation with SNV
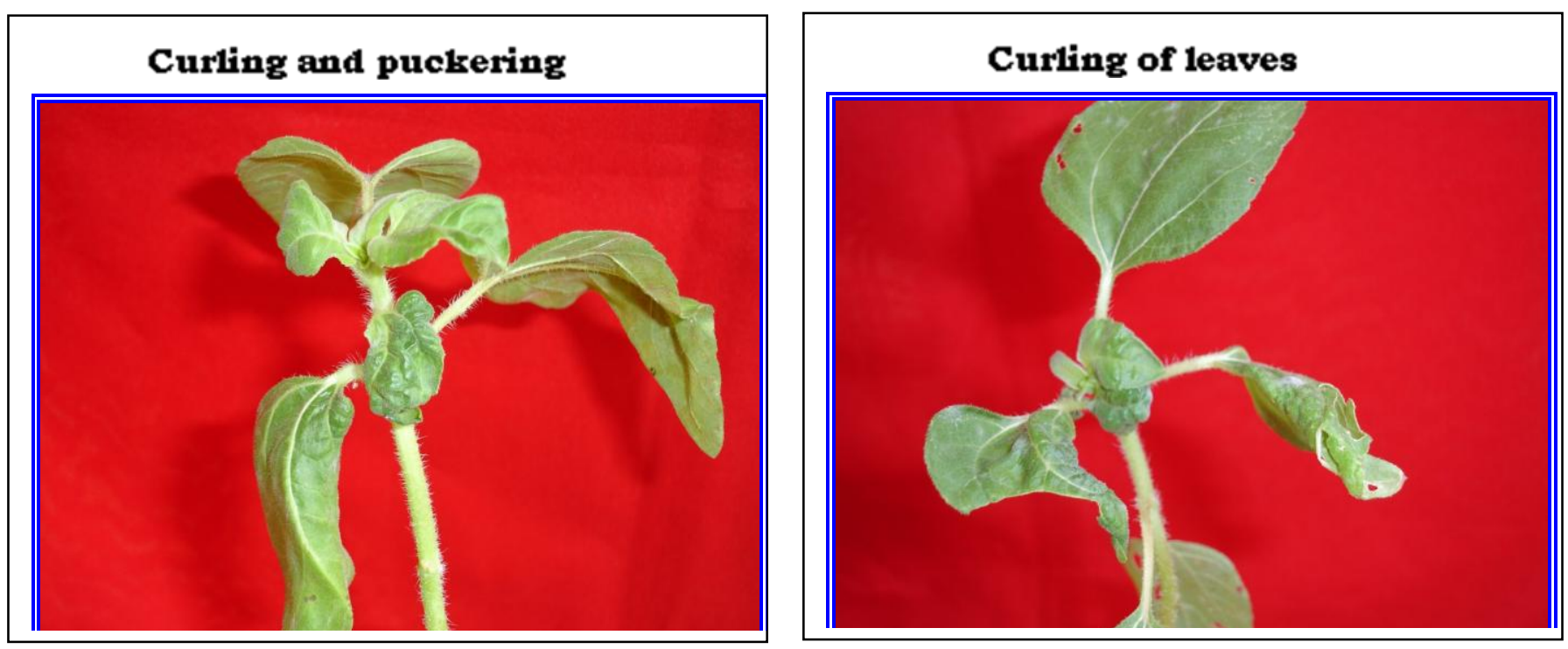
Plate.2 Detection of SNV in Mechanically sap transmitted sunflower plants through RT-PCR. Lane: (M) Marker; Lane1: KBSH 1; Lane 2: KBSH 44; Lane: 3 Morden; and Lane 4: Healthy sunflower

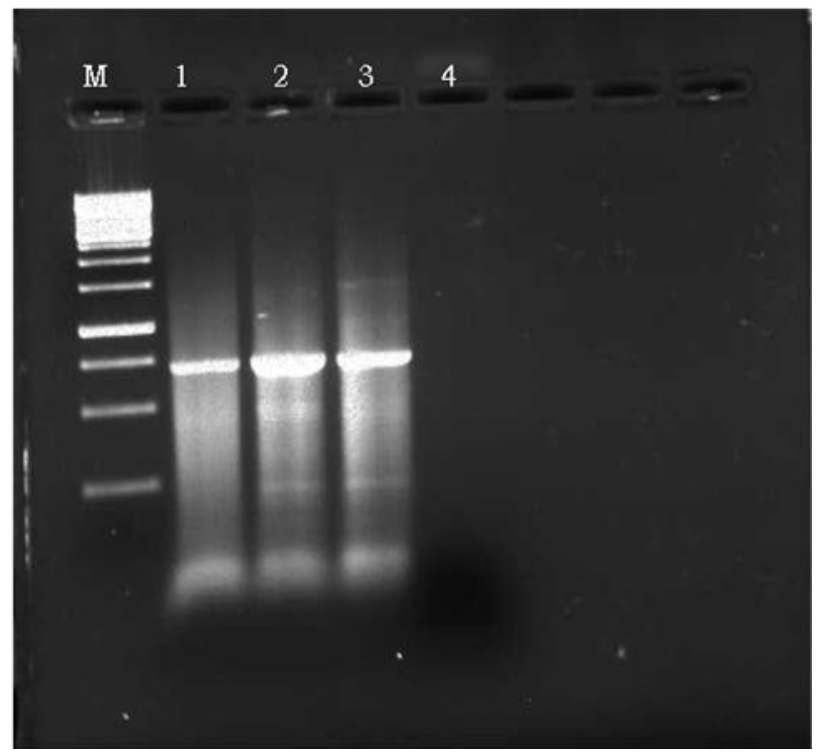

The sunflower genotypes (KBSH 1, KBSH 44, Morden) after subjecting for artificial inoculation of the virus through mechanical sap were subjected for DAC-ELISA (Table1). A positive reaction with Tobacco Streak Virus (TSV) antisera was obtained in all the three genotypes indicating the presence of SNV in the leaf samples. These results thus prove the transmissible nature of SNV through mechanical sap method. Similar results were reported by Linga Reddy (2003) and Linga Reddy and Nagaraju (2006).

The RT-PCR reaction was performed using RKJ primers specific for the coat protein gene of TSV and resulted in an amplicon of the expected size approximately 700bp (Plate 2). These results thus prove the transmissible nature of SNV through mechanical sap method in The sunflower genotypes KBSH 1, KBSH 44 and Morden. The results were similar to that obtained by (Bhat et al., 2002) on analysis of sunflower samples from Aurangabad, Bangalore, Coimbatore and Hyderabad. Pankaja (2007) showed presence of SNV by RT-PCR in sunflower, Groundnut, Cowpea, Water melon and Tobacco produced an amplified DNA product of approximately $700 \mathrm{bp}$ in size.

\section{References}

Ajith Prasad, H. N., 2004, Transmission and serological diagnosis of sunflower necrosis virus from various sources and screening for resistance. M.Sc. (Agri.) Thesis, Univ. Agri. Sci., Bangalore, 99 pp.

Anil Kumar, H. R., 1999, Studies on sunflower necrosis virus disease. M.Sc. (Agri.) Thesis, Univ. Agri. Sci., Bangalore, $102 \mathrm{pp}$.

Anonymous, 1997, Ann. Prog. Rep. of ACIRP on Oilseeds (Sunflower). Directorate of Oilseed Research. ICAR, Hyderabad, India, 167 pp.

Bhat, A. I, Jain, R. K. and Ramiah, M., 2002, Detection of Tobacco Streak Virus from sunflower and other crops by reverse transcription polymerase chain 
reaction. Indian Phytopath., 55: 216218.

Kolte, S. J., 1985, Sunflower diseases. In: Diseases of Annual Edible Oilseed Crops, III, and CRC press, Florida, $194 \mathrm{pp}$.

Linga Reddy, G. and Nagaraju, 2006, Serological detection of sunflower necrosis virus disease. Environ. Ecol., 24: $52-54$.

Linga Reddy, G., 2003, Transmission and serological indexing of weed hosts, crop plants and insect vector of sunflower necrosis disease. M.Sc. (Agri.) Thesis, Univ. Agri. Sci., Bangalore, $85 \mathrm{pp}$.

Nagaraju, 1995, Studies on sunflower mosaic virus disease. Ph.D. Thesis, Dept. of Plant pathology, Univ. Agri. Sci., Bangalore, $157 \mathrm{pp}$.

Nagaraju, Channakrishnaiah, K. M., Ramesh, S. and Anil Kumar, H. R., 1998, Monitoring the new sunflower necrosis disease and screening the entries of coordinated trials at Bangalore. In: Integrated Disease Management and Crop Loss Assessment (Eds. Nagaraju et al.,), pp 60-61, Dec. 10-12. IPS (S Zone)/ Uni. Agric. Sci., Bangalore, 74 pp.
Pankaja, N. S., 2007, Epidiomology and molecular diagnosis of sunflower necrosis virus (SNV) on sunflower (Helianthus annuus L.) Ph.D Thesis, Univ. Agri. Sci., Bangalore, 207 pp.

Prasada Rao, R. D. V. J., Reddy, A. S., Chander Rao, S., Varaprasad, K. S., Thirumala Devi, K., Nagaraju, Muniyappa, V., Reddy, D.V.R., 2000, Tobacco streak ilarvirus as causal agent of sunflower necrosis disease in India. J. Oilseeds Res., 17: 400-401.

Sambrook, J., Fritsch,E.F. and Maniatis, T., 1989, Molecular cloning: a laboratory manual, 2nd edn. Cold Spring Harbor Laboratory Press, Cold Spring Harbor, 3 volumes.

Shivasharanayya, 2000, Transmission, screening for resistance and epidemiology of sunflower necrosis virus disease. M.Sc. (Agri.) Thesis, Univ. Agri. Sci., Bangalore, 121 pp.

Singh, S. J., Nagaraju, Krishna Reddy, M., Muniyappa, V. and Virupakshappa, K., 1997, Sunflower necrosis a new virus disease from India. In: Nat. Sympo. Eco. Imp. Dieases of Crop Plants; pp 24: Dec 18-20. IPS (S-Zone) Uni. Agric. Sci., Bangalore 74 pp.

\section{How to cite this article:}

Ravi Kumar, B. Jagadeesha, N. Gajanana Kustagi, K.R. Lingamurthy, N. Ashoka and Nagaraju. 2019. Paddy Crop Status in Tamil Nadu - A Statistical Analysis. Int.J.Curr.Microbiol.App.Sci. 8(02): 3203-3208. doi: https://doi.org/10.20546/ijcmas.2019.802.374 